\title{
Instructional Design for Advanced Learners: Establishing Connections between the Theoretical Frameworks of Cognitive Load and Deliberate Practice
}

Citation for published version (APA):

Van Gog, T., Ericsson, K. A., Rikers, R., \& Paas, F. (2005). Instructional Design for Advanced Learners:

Establishing Connections between the Theoretical Frameworks of Cognitive Load and Deliberate Practice.

Educational Technology, Research and Development, 53(3), 73-81. https://doi.org/10.1007/BF02504799

DOI:

10.1007/BF02504799

Document status and date:

Published: 01/09/2005

Document Version:

Peer reviewed version

Please check the document version of this publication:

- A submitted manuscript is the version of the article upon submission and before peer-review. There can be important differences between the submitted version and the official published version of record. People interested in the research are advised to contact the author for the final version of the publication, or visit the DOI to the publisher's website.

- The final author version and the galley proof are versions of the publication after peer review.

- The final published version features the final layout of the paper including the volume, issue and page numbers.

Link to publication

\section{General rights}

Copyright and moral rights for the publications made accessible in the public portal are retained by the authors and/or other copyright owners and it is a condition of accessing publications that users recognise and abide by the legal requirements associated with these rights.

- Users may download and print one copy of any publication from the public portal for the purpose of private study or research.

- You may not further distribute the material or use it for any profit-making activity or commercial gain

- You may freely distribute the URL identifying the publication in the public portal.

If the publication is distributed under the terms of Article 25fa of the Dutch Copyright Act, indicated by the "Taverne" license above, please follow below link for the End User Agreement:

https://www.ou.nl/taverne-agreement

Take down policy

If you believe that this document breaches copyright please contact us at:

pure-support@ou.nl

providing details and we will investigate your claim.

Downloaded from https://research.ou.nl/ on date: 26 Apr. 2023 


\title{
Instructional Design for Advanced Learners: Establishing Connections between the Theoretical Frameworks of Cognitive Load and Deliberate Practice
}

\author{
Tamara van $\operatorname{Gog}^{1}$, K. Anders Ericsson ${ }^{2}$, Remy M. J. P. Rikers ${ }^{3}$ and Fred Paas ${ }^{1}$ \\ ${ }^{1}$ Educational Technology Expertise Center, Open University of the Netherlands \\ ${ }^{2}$ Psychology Department at Florida State University, Florida, USA \\ ${ }^{3}$ Psychology Department at Erasmus University Rotterdam, The Netherlands
}

Cognitive load theory (CLT) has been successful in identifying instructional formats that are more effective and efficient than conventional problem solving in the initial, novice phase of skill acquisition. However, recent findings regarding the "expertise reversal effect" have begun to stimulate cognitive load theorists to broaden their horizon to the question of how instructional design should be altered as a learner's knowledge increases. To answer this question, it is important to understand how expertise is acquired and what fosters its development. Expert performance research, and, in particular, the theoretical framework of deliberate practice have given us a better understanding of the principles and activities that are essential in order to excel in a domain. This article explores how these activities and principles can be used to design instructional formats based on CLT for higher levels of skills mastery. The value of these formats for e-learning environments in which learning tasks can be adaptively selected on the basis of online assessments of the learner's level of expertise is discussed.

Educational Technology Research and Development, 53(3), 73-81

http://www.springerlink.com/content/q813420202j4n811/

(C) 2005 Springer, all rights reserved 